\title{
Transboundary Ecological Conservation, Environmental Value, and Environmental Sustainability: Lessons from the Heart of Borneo
}

\author{
Choy Yee Keong ${ }^{1,2, *}$ and Ayumi Onuma ${ }^{1}$ \\ 1 Faculty of Economics, Keio University, 2-15-45 Mita, Minato-ku, Tokyo 108-8345, Japan; \\ onuma@econ.keio.ac.jp \\ 2 Institute of Biodiversity and Environmental Conservation (IBEC), Universiti Malaysia Sarawak, \\ Ensurai 94300, Sarawak, Malaysia \\ * Correspondence: choy3293@gmail.com; Tel.: +81-80-5093-3293
}

Citation: Keong, C.Y.; Onuma, A.

Transboundary Ecological

Conservation, Environmental Value, and Environmental Sustainability: Lessons from the Heart of Borneo. Sustainability 2021, 13, 9727. https:// doi.org/10.3390/su13179727

Academic Editor: Alejandro Rescia

Received: 28 July 2021

Accepted: 26 August 2021

Published: 30 August 2021

Publisher's Note: MDPI stays neutral with regard to jurisdictional claims in published maps and institutional affiliations.

Copyright: (c) 2021 by the authors. Licensee MDPI, Basel, Switzerland. This article is an open access article distributed under the terms and conditions of the Creative Commons Attribution (CC BY) license (https:// creativecommons.org/licenses/by/ $4.0 /)$.

\begin{abstract}
Balancing economic growth with international commitments to environmental sustainability is a global challenge. One of the main objectives of this study is to address this challenge by stimulating and sustaining motivation for environmental conservation by means of a comprehensive rethinking of the values inherent in nature and the limitations of monetary approaches to biodiversity valuation. This is achieved based on a case study of a transboundary ecological conservation project, the Heart of Borneo (HoB) in Borneo Island, covering Kalimantan in Indonesia, Borneo Malaysia comprising the states of Sarawak and Sabah, and Brunei Darussalam. This study synthesizes critical insights into the multiple ranges of life-supporting environmental values embedded in the HoB natural capital to enhance stronger motivations for environmental conservation. The study also reports on evidence gathered from extensive field studies conducted in Borneo Malaysia, confirming the correlations between environmental beliefs in value pluralism, ecological action, and environmental sustainability, and its implications for sustainable resource use and management. The synthesis is expected to serve as practical guidance for sustainable resource and environmental management decision-making, which is conceptually and universally applicable.
\end{abstract}

Keywords: transboundary ecological conservation; indigenous adat (custom); value monism; value pluralism; ecocentrism; anthropocentrism; environmental sustainability

\section{Introduction}

Environmental decisions affect the natural system and people in diverse ways. For example, while massive conversion of forests to oil palm plantations results in enormous economic benefits in export earnings, it will also lead to extensive habitat destruction. This, in turn, produces an expanding web of adverse environmental effects that impact biodiversity's ecological resilience and the natural resource-dependent indigenous forest dwellers. The complex dynamics of these human-economic-environmental relationships reflect the divergence of stakeholder value judgments and perspectives in relation to the corrective treatment of environmental values that underpin resource use patterns.

To policy makers, the natural environment is conveniently embraced as a means for the enhancement of socio-economic prosperity. This is the monist view of nature in which natural resources are instrumentally being monetized. Here, environmental conservation matters only insofar as overexploitation negatively impacts the continuous flow of economic benefits or results in an undue reduction of nature's inherent economic values, economic activity, or future productivity - an economically driven mode of environmental conservation. Generally speaking, this is the standard monodisciplinary approach of development premised on value monism and anthropocentric (human-centered) behavioral orientation. Value monism is the philosophical idea that all of our moral beliefs ought to be 
reduced to a single guiding principle or one overarching value. This is the highest-ranking policy option for sustainable resource use in today's human-centered world, where a high value is placed on economic prosperity over environmental conservation.

However, to the indigenous forest dwellers, the natural environment is widely viewed as a natural system embedded in a web of cultural, social, ecological, and economic values. Their resource use patterns are intrinsically based on a diversity of interests, plurality of values, and cultural or ethical positions; this is called value pluralism. Value pluralism is the thesis that there are many environmental values (monetized and unmonetized) that cannot be monetarily reduced to a superlative value. This has important implications for the rational choice of sustainable resource use practices [1,2].

Thus, values play an important role in environmental policy and resource management. However, the ways in which values are perceived and recognized in decision-making are complex because they entail an interplay of different meanings, environmental worldviews, and the perceptions of sustainability. However, its wide spectrum of values, which underscore the perceptions of the natural environment and the motives for environmental conservation, are rarely recognized or explicitly taken into account in dominant resource development decision-making. Identifying and recognizing these values is, thus, crucial for guiding sustainable resource use and policymaking.

\section{Research Aim and Methodology}

The main aim of the present study is to develop a typology of environmental values that can aid practitioners and policymakers in sustainable environmental planning and management. This is achieved based on a case study of the Heart of Borneo (HoB) trinational protected ecological system in Borneo Island. In particular, it seeks to examine the pluralist values inherent in the $\mathrm{HoB}$ ecological system and ascertain the fundamental value determinants of environmental concern and resource use patterns. The study also aims to show the contrast between unsustainable development practices driven by an ethics of anthropocentrism against ecocentric efforts of protection in the Heart of Borneo, and the necessity of policy emphasis on plurality in environmental values. The evaluation will focus on Indonesia and Malaysia, the two largest local ecological systems in the HoB.

In support of the above analysis, we report empirical evidence based on data collected from field research conducted in Borneo Malaysia between 2007 and 2010, and between 2017 and 2018. Fieldwork and face-to-face interviews with indigenous people were conducted between 2007 and 2010, covering 495 individuals from various tribal groups in 50 villages, mostly located in the forest interior in Bintulu, Miri, Sibu, Mulu, and Kuching, and between 2017 and 2018 in Sarawak (Kuching) covering 272 Bidayuh, Sabah (Kota Kinabalu) covering 39 Dusun, and 21 Kadazan indigenous people. The total number of people interviewed was 827 individuals. Interviews were primarily conducted in the Malay language through random house visits and field encounters and all translations into English are mine (corresponding author).

An overall sampling frame of 827 individuals comprising 392 males and 435 females from various indigenous groups in different places were selected to provide comparable qualitative individual attributes data spread across different tribal communities from different geographical locations. The aim of the interview was to identify the environmental behavioral characteristics fundamental to the deduction of values that underpin the local people's environmental practices. Interview questions were designed to focus on the indigenous people's preference and reasoning for their environmental practices. The data were evaluated using a deductive content analysis approach.

The evidence provides an insightful classification of values that mirror the benefits provided by the HoB ecosystem, which contribute to a range of benefits (monetized and unmonetized) that underpin the various aspects of social, economic, and environmental sustainability (the three pillars of sustainable development). Environmental sustainability is defined as responsible human decisions and actions when optimizing the economic use of nature, with the view to sustain its ecological integrity [2]. Overall, the analysis 
sheds light on the critical fact that the way we conceptualize and integrate environmental values in decision-making has far-reaching implications for sustainable resource use and environmental sustainability.

Remarkably, thus far, no serious attempt has been made to conceptually evaluate the inherent complexity and diversity of nature-based values ascribed to the HoB's ecosystem that underpin environmental sustainability. To be sure, the conservation of HoB has been widely discussed over the past two decades, and there is now widespread awareness of the urgent need to protect the "values" of HoB for its economic, environmental, and social importance [3-6]. This is an underrepresented category of value classification because it lacks conceptual clarity and precision as to what specific forms of value we have to protect, how they are attributed or articulated, the interlinked pattern of these values, and the extent to which it supports environmental sustainability. As will be revealed in the subsequent section, the current marginalized perspective of $\mathrm{HoB}$ value representation is unlikely to serve as a useful guide toward achieving environmental sustainability in the region.

Hence, the present study, framed under concrete research settings based on theoretical assessments and supported by empirical evidence, contributes to a greater understanding of how the broad spectrum of values attributable to the HoB serve as a cornerstone of environmental sustainability. It also allows us to gain insight into the art of sustaining our environment, which hinges on our commitment to balancing various human economic interests with nature's value pluralism. In addition, despite the burgeoning literature on the issue of environmental value, the role of value pluralism in promoting environmental sustainability has rarely been empirically supported based on actual field research. Thus, an incredibly important component of this study is the solid evidence gathered from actual field work in support of the theoretical assessment of the concepts of value pluralism. The current study is expected to provide a remarkable evaluative framework for sustainable resource use and management, which is universally relevant.

\section{Literature Review: The Concept of Value}

This section provides a brief discussion of the concept of value in order to lay the foundation for the analysis that follows. To begin with, consciously or otherwise, people attach values to aspects that are important in their lives. From an environmental perspective, values are central to the patterns of resource use because they point toward various aspects of human life-social, economic, ethical, and cultural, among others. However, there is no such established universal meaning of value because it means different things to different people and under different situations or disciplines $[1,2,7,8]$. In the theory of value, an individual ascribes value to things in light of what value means to him. In other words, it means anything that has value or is valuable to him [7]. The act of ascribing value to things is emotional in that it is a conscious expression of an interest, be it economic, environmental, or ethical [8]. Thus, when he claims that he values a thing highly because it possesses certain characteristics, it means that he emotionally cares greatly for it, thus, giving it a high value [7].

By extension, this may translate to mean that value represents an "object of interest" or a "genuine desire," as distinct from a mere wish or need or a desirable end state, which induces personal actions or efforts for its realization [7-9]. It may, thus, be summed up that values are fundamentally a relation between humans and various aspects or attributes of the social or environmental world within which they exist. Values serve as a significant means to justify and motivate actions that an individual considered as desirable or morally right. In other words, they are significantly linked to specific attitudes and beliefs regarding to, for example, what is right and wrong when optimizing the economic use of nature. More specifically, they serve as a normative proposition with a prescriptive nature in influencing the selection from available modes, means, and ends of actions in order to maximize the greatest good for the greatest numbers, which may be expressed in terms of profit maximization or social welfare optimization $[10,11]$. 


\section{The Heart of Borneo: The World's Ecological Treasure Trove}

First, a brief introduction of the Heart of Borneo (HoB) is in order. The HoB is situated in Borneo, the third-largest island in the world next to Greenland and New Guinea. It is shared by Indonesia (Kalimantan) covering an area of 745,567 square kilometers $\left(\mathrm{km}^{2}\right)$, Borneo Malaysia, comprising the states of Sarawak and Sabah with an area of $124,449 \mathrm{~km}^{2}$ and $73,711 \mathrm{~km}^{2}$, respectively, and a small-nation sate, Brunei Darussalam $\left(5765 \mathrm{~km}^{2}\right)$. The rainforests in Borneo, which evolved between 100 and 150 million years ago, are among the most biologically diverse on Earth.

Representing just one percent of the earth's terrestrial surface, the island of Borneo holds about six percent of the world's plant and animal species. There are approximately 15,000 flowering plants and 3000 species of trees found in Borneo's forest, including 6000 endemic species. The biologically diverse island is recognized as a globally significant biodiversity 'hotspot'. In addition, the uplands of Borneo are a source of at least 14 of the 20 major rivers on the island $[4,12,13]$. Thus, environmentally sustainable resource management is critically important in maintaining the ecological health of riverine systems, which underpin the socio-economic progress of 17 million people in Borneo.

In an attempt to protect the environmental integrity of the ecological treasures of Borneo, the governments of Indonesia, Malaysia, and Brunei Darussalam, in cooperation with the World Wildlife Fund for Nature (WWF), formally created a regional environmental protection framework known as the Heart of Boneo Initiative (HoBI) in 2007. This trilateral initiative also aims to promote sustainable development that improves the welfare of the local people. The adoption of HoBI resulted in the initial mapping of 23 million hectares of natural landscape straddling the transboundary highlands of Kalimantan in Indonesia and the states of Sarawak and Sabah in Borneo Malaysia, and extending to the foothills in adjacent lowlands and parts of Brunei Darussalam for conservation purposes. This massive transboundary ecological system is known as the Heart of Borneo (HoB) (Figure 1).

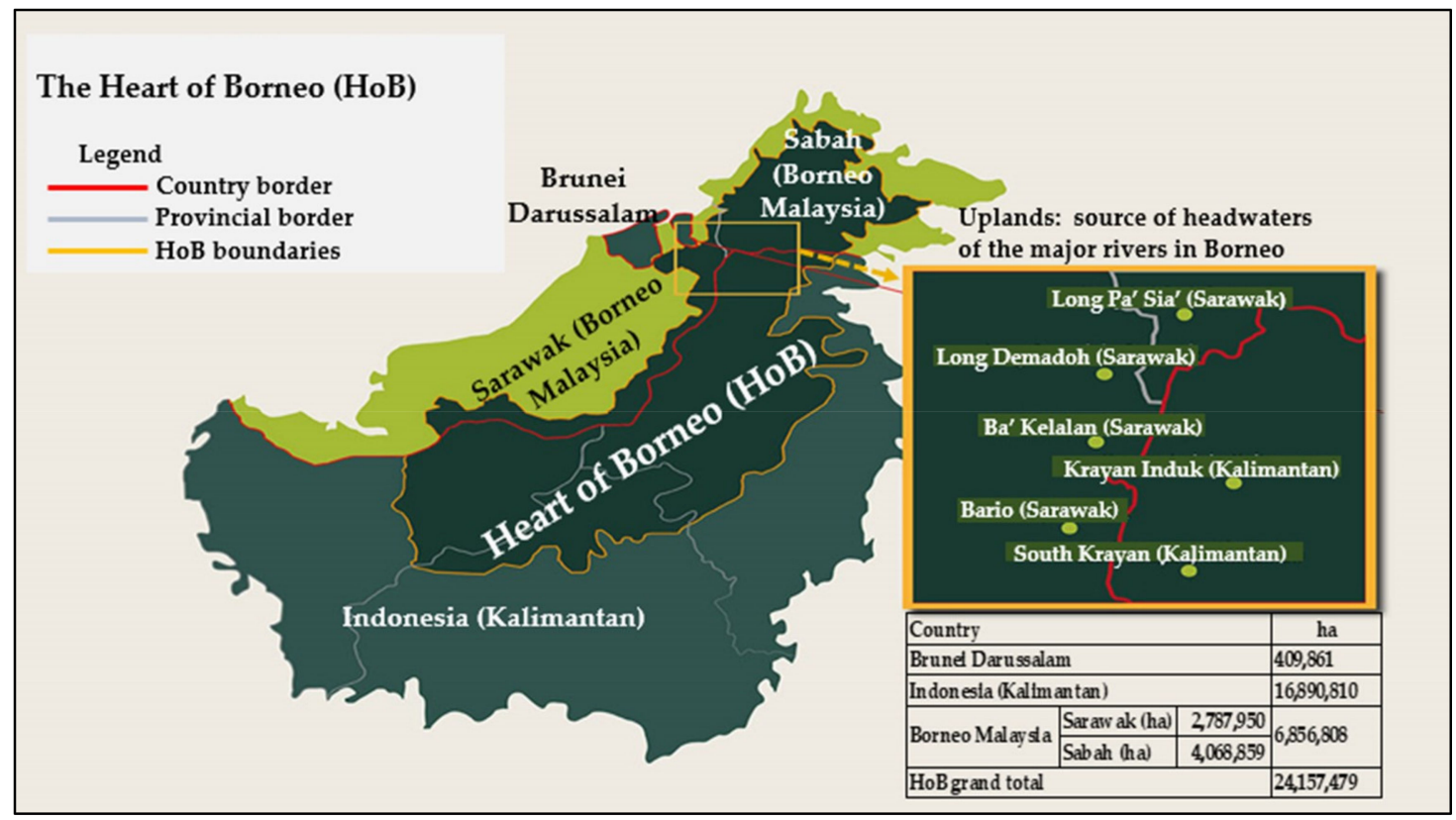

Figure 1. The Heart of Borneo location.

The HoB lies across 60 percent of the total area in Kalimantan (16.8 million ha), about 38 percent of Borneo's landmass, Borneo Malaysia (six million ha), and just under two percent (340,000 ha) in Brunei Darussalam. Later, it was increased to 2.4 million ha, with Sarawak and Sabah expanding their Protected Area networking to HoB by an addition of 600,000 and 125,865 ha, respectively (Table 1). In 2018, Sarawak extended its HoB areas further to 2.69 million ha, extending from Batang Ai to the western region of Sarawak [14]. 
It may be noted that most of Sabah's forests are located within the HoB while most of the HoB areas in Sarawak are located in the highlands, which are essential watersheds that contain the headwaters of the Baleh, Murum, and Bakun dams [15].

Table 1. The composition of the Heart of Borneo.

\begin{tabular}{|c|c|c|c|}
\hline Country & Region & ha & ha \\
\hline \multirow{3}{*}{ Brunei Darussalam } & Belait & 264,005 & \\
\hline & Temburong & 94,785 & \\
\hline & Tutong & 51,071 & \\
\hline \multicolumn{3}{|c|}{ Brunei Darussalam HoB sub-total } & 409,861 \\
\hline \multirow{4}{*}{ Indonesia } & West Kalimantan & $4,916,316$ & \\
\hline & Central Kalimantan & $3,008,377$ & \\
\hline & East Kalimantan & $3,756,673$ & \\
\hline & North Kalimantan & $5,209,443$ & \\
\hline & Indonesia HoB sub-total & & $16,890,810$ \\
\hline \multirow{2}{*}{ Malaysia } & Sarawak & $2,787,950$ & \\
\hline & Sabah & $4,068,859$ & \\
\hline & Malaysia HoB sub-total & & $6,856,808$ \\
\hline & Borneo HoB grand total & & $24,157,479$ \\
\hline
\end{tabular}

The HoB, which represents roughly 30 percent of Borneo's landmass, is one of the world's largest remaining transboundary rainforests. It is home to a range of threatened species, including orangutans, pygmy elephants, clouded leopards, proboscis monkeys, and the critically endangered Sumatran rhino. Since 1995, more than 500 new species have been discovered within the HoB [3]. The HoB also serves as a life-support system to provide various ecosystem services to approximately 11 million people in Borneo [16]. Approximately one million indigenous people depend directly on HoB's natural resources for socio-economic sustenance and cultural practices $[13,16]$. The HoB is not only the key watershed area for the provision of water ecosystem services on the island, but also serves a critically important function in regulating local, regional, and global warming.

\section{The Heart of Borneo Transboundary Resource and Environmental Management System}

The HoB Strategic Action Plan (HSAP) was formulated under the HoBI to enhance regional cooperation to promote sustainable resource use and management practices on the island. The plan also aims to promote green economic transformation in the HoB region. Within the present context, the HoB green economic transformation may be defined as a development strategy that meets the need to balance the three pillars of sustainable development, namely, environmental, economic, and social sustainability. The following strategic means were designed under the HSAP to guide the direction of this green transformation process (Figure 2):

1. Transboundary management: to promote environmental sustainability

2. Protected area management: to promote environmental sustainability

3. Sustainable resource management: to promote environmental sustainability

4. Ecotourism development: to promote socio-economic sustainability

5. Capacity building: to enhance individual/organization's capability/capacity 


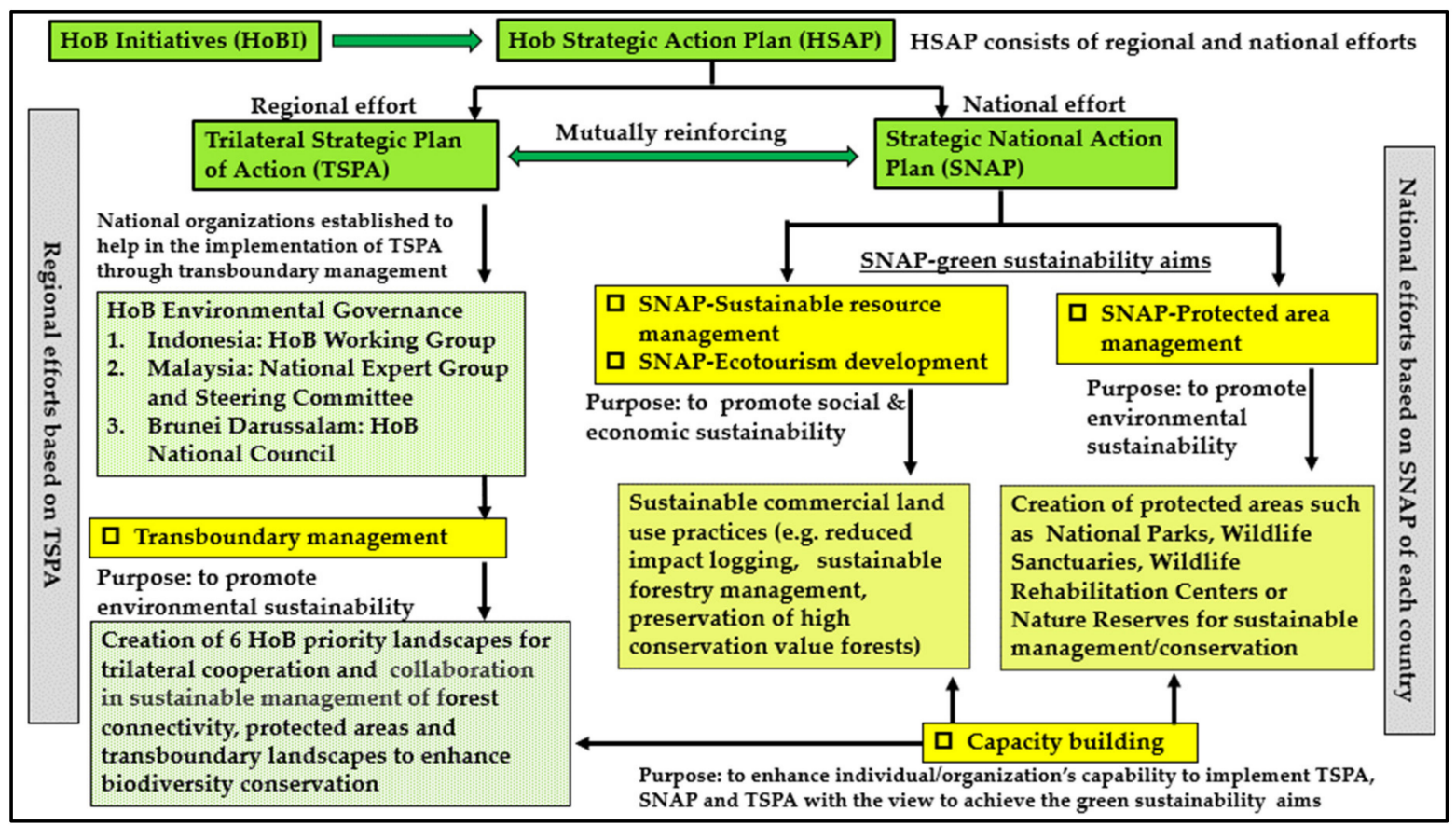

Figure 2. The Heart of Borneo framework of green economic transformation.

With reference to Figure 2, the HSAP may be explained from a regional and national perspective. From a regional perspective, leaders from all member countries agreed to establish a Trilateral Strategic Plan of Action (TSPA) to serve as a general guide for transboundary management of the forest connectivity of mountain ranges. This Action Plan aims to conserve the ecological integrity of $\mathrm{HoB}$ transboundary wildlife connectivity corridors to protect various endangered species such as Borneo orangutans, Borneo pygmy elephants, Kalimantan hornbill, and Muller's gibbon, among others, that thrive in the regions. Six transboundary $\mathrm{HoB}$ landscapes comprising various national parks, jungle of forest reserves, and conservation areas were established to expedite biological and environmental conservation efforts (Figure 3).

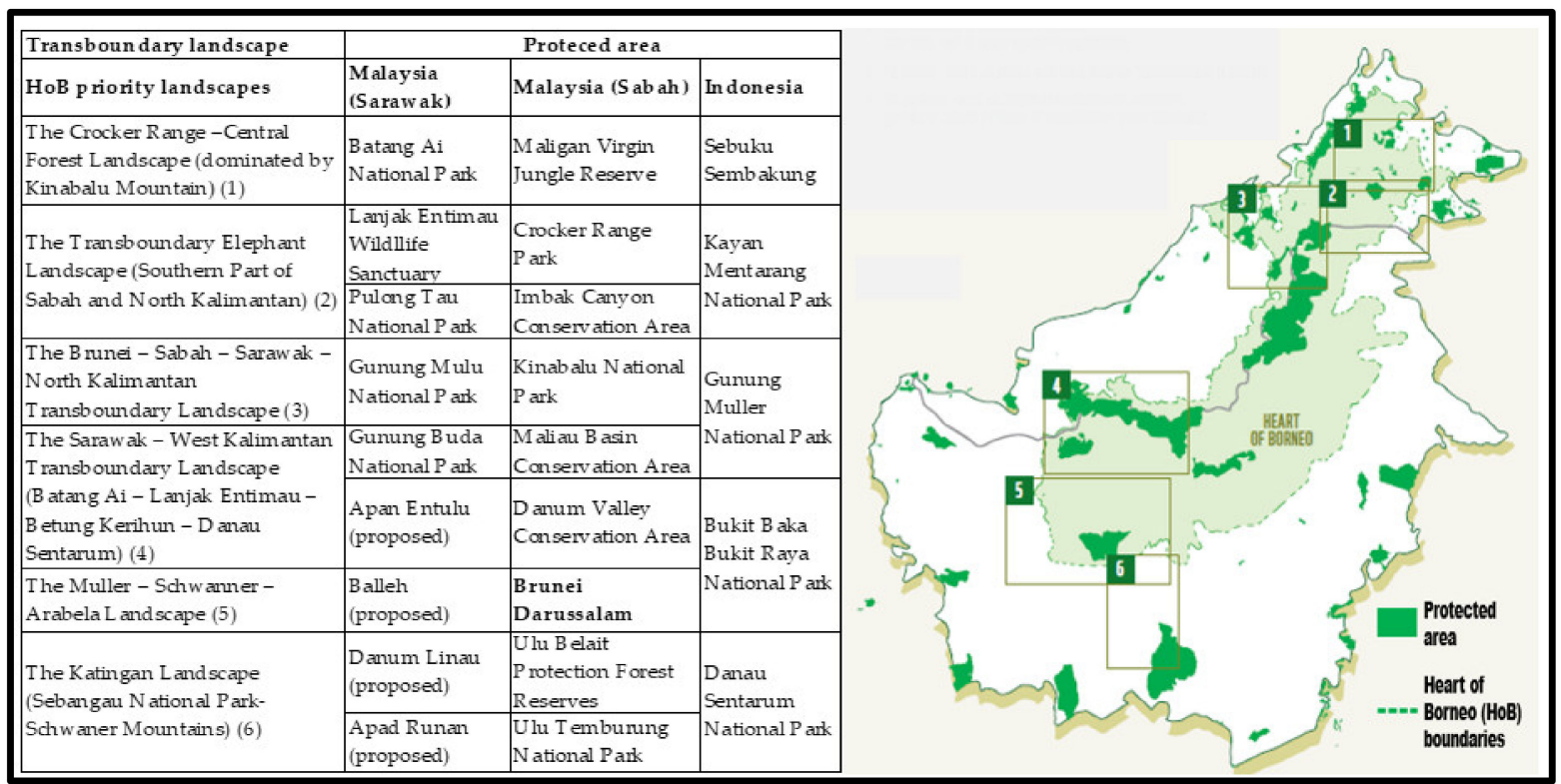

Figure 3. The Heart of Borneo priority/transboundary landscapes. Source: $[4,17]$. 
Figure 3 may be briefly summarized as follows:

1. The Crocker Range-Central Forest Landscape is dominated by the Kinabalu Mountain. It embraces various protected areas such as the Maliau Basin Conservation Area, Imbak Canyon Conservation Area, and Danum Valley Conservation Area in Sabahcollectively known as the DaMaI (Danum-Maliau-Imbak).

2. The Transboundary Elephant Landscape covers the southern part of Sabah and North Kalimantan and is dominated by the Sebuku Sembakung Park (North Kalimantan). The Park contains one of the most complete concentrations of biodiverse species in Borneo.

3. The Brunei-Sabah-Sarawak-North Kalimantan Transboundary Landscape is a trilateral landscape that provides connectivity from Brunei to North Kalimantan through Sabah and Sarawak. It includes eight national parks from three countries: Kinabalu (Sabah), Gunung Mulu (Sarawak), Kayan Mentarang (northern part of East Kalimantan), and Ulu Temburung (Brunei).

4. The Sarawak-West Kalimantan Transboundary Landscape comprises the Batang Ai National Park (Sarawak), Lanjak Entimau Wildllife Sanctuary (Sarawak), Danau Sentarum National Park (Kalimantan), and Betung Kerihun National Park (Kalimantan).

5. The Muller-Schwanner-Arabela Landscape is a connection between Muller Mountain and Schwaner Central Mountain.

6. The Katingan Landscape provides an ecological connection between the Schwaner Mountains and Sebangau National Park (peat swamp forest type), with surrounding carbon-rich peat lands adjoining it. It also covers part of the Bukit Baka-Bukit Raya National Park (highland forest type) in the Schwaner Mountains.

From a national perspective, to reinforce regional transboundary management, each country has formulated its own Strategic National Action Plan (SNAP) to guide: (i) sustainable resource management, (ii) ecotourism development, and (iii) protected area management. To reinforce regional transboundary management, each country has established a network of protected areas such as national parks, wildlife reserves, and forests to enhance biological conservation, especially in the shared border areas (environmental sustainability). Notably, some parts of the HoB designated area already had a protected status before establishing the HoB trilateral ecological system. In total, as shown in Figure 3, 23 protected areas, including four proposed areas, were established or reaffirmed within the $\mathrm{HoB}$ region. Protected area management also serves as a critical means to enhance biological conservation while promoting sustainable economic use of natural resources in the region. Ecotourism has the promotion of social equity and environmental sustainability at its core. It emphasizes the positive effects of employment and revenue generation through nature adventure and indigenous culture promotion to enhance social equity (social and economic sustainability).

To further enhance regional trilateral conservation efforts, the three member countries of the HoB program have committed to further strengthening the local capacity of the relevant stakeholders in sustainable resource use and management, environmental governance, technical capability, planning and development, and policy formulation, among others (capacity building). From an environmental governance perspective, each country has already put in place various environmental laws to protect the environment and natural resources [2].

\section{The Heart of Borneo Transboundary Environmental and Resource Management in Practice}

The HoB framework serves as an important platform for implementing a range of sustainable management and conservation projects on the ground. However, due to socioeconomic and political reasons, the contribution and type of involvement of each country may differ. Regardless, their natural resource management practices would follow the WWF Green Economy model whereby the HoB forests should be sustainably used and managed through reduced impact logging, selective cutting, and international certification 
of sustainable forest management (economic and environmental sustainability) [3]. At the same time, plantation development would only take place in highly degraded or deforested areas that are not high conservation value forests (HCVF) [3]. High conservation value forests are defined as forests that are more appreciated for biodiversity, ecological, social, and cultural values than economic value.

Under the HSAP, various programs, as demonstrated below, have been devised and implemented to sustainably manage forest resources to meet the green objectives of social, economic, and environmental sustainability. As shown in Table 2, which is self-explanatory, Indonesia has established the following three major conservation programs to promote environmental conservation:

i. The West and Central Kalimantan Program to promote sustainable management of the Muller-Schwaner-Arabela Landscape, which is home to a wide range of endangered species.

ii. The West Kalimantan Program to enhance capacity building in environmental conservation and ecotourism development.

iii. The East and North Kalimantan Program to enhance capacity building in environmental management.

In Malaysia, the Sabah state government has established the Sabah Terrestrial Conservation Program to enhance environmental conservation through protected area management. As a result, the ecological integrity of the HoB DaMaI (Danum-Maliau-Imbak) ecosystem has improved greatly. In Sarawak, the state government has set up the Sarawak Conservation Program to expedite environmental conservation efforts through protected area management.

Table 2. The Heart of Borneo transboundary environmental programs.

\begin{tabular}{|c|c|c|c|}
\hline & Indonesia & & Malaysia \\
\hline $\begin{array}{l}\text { West and } \\
\text { Central } \\
\text { Kalimantan } \\
\text { Program }\end{array}$ & $\begin{array}{l}\text { To promote landscape level sustainable } \\
\text { development and on-site environmental } \\
\text { conservation of the Muller-Schwaner-Arabela } \\
\text { Landscape which is home to a number of } \\
\text { endangered species such as orangutan, } \\
\text { Kalimantan hornbill, Malayan sun bear and } \\
\text { Muller's gibbon. The scope of conservation covers } \\
10 \text { districts and a forest block called the Gunung } \\
\text { Lumut conservation area (comprising 28,548 ha). }\end{array}$ & \multirow{4}{*}{$\begin{array}{l}\text { Sabah } \\
\text { Terrestrial } \\
\text { Conservation } \\
\text { Program }\end{array}$} & \multirow{2}{*}{$\begin{array}{l}\text { Reclassified 13,810 ha of Maliau Basin } \\
\text { Conservation Area from Class II (production) to } \\
\text { Class I (protection) Forest Reserve to enhance } \\
\text { environmental protection. The connectivity of } \\
\text { existing protected areas including Maliau Basin, } \\
\text { Imbak Canyon, and Danum Valley, known as the } \\
\text { HoB DaMaI (Danum-Maliau-Imbak) ecosystem, } \\
\text { has improved greatly. In addition, about 470,000 } \\
\text { ha of forest within the HoB have been restored } \\
\text { through the participation of the local communities } \\
\text { [Class I forests are totally protected by law]. }\end{array}$} \\
\hline \multirow{3}{*}{$\begin{array}{l}\text { West } \\
\text { Kalimantan } \\
\text { Program }\end{array}$} & $\begin{array}{c}\text { Capacity building was conducted on various } \\
\text { aspects of management for local organization in } \\
\text { two districts, Sintang and Hulu Kapuas located in } \\
\text { the upper Kapuas region. }\end{array}$ & & \\
\hline & $\begin{array}{l}\text { A number of forums including the community } \\
\text { forum and sustainable palm oil forum were } \\
\text { established to promote the documentation of } \\
\text { indigenous social-culture and customary law and } \\
\text { to share various environmental and development } \\
\text { experiences and lessons among the } \\
\text { relevant stakeholders. }\end{array}$ & & \multirow[t]{2}{*}{$\begin{array}{c}\text { WWF supported the establishment of an } \\
\text { anti-poaching task force comprising the Sabah } \\
\text { Forestry Department (SFD), Sabah Wildlife } \\
\text { Department, Yayasan Sabah and the Police } \\
\text { Department (PDRM). }\end{array}$} \\
\hline & $\begin{array}{c}\text { Various national and district level seminars on } \\
\text { District Strategic Area for the Labian-Leboyan } \\
\text { Corridor which features orangutan conservation } \\
\text { work were conducted. }\end{array}$ & & \\
\hline
\end{tabular}


Table 2. Cont.

\begin{tabular}{|c|c|c|c|}
\hline & Indonesia & & Malaysia \\
\hline & $\begin{array}{l}\text { WWF raised evidence produced by Eyes on the } \\
\text { Forest (EoF) to pressure the government to take } \\
\text { action against corporations involved in illegal and } \\
\text { environmentally destructive land use practices. }\end{array}$ & \multirow{5}{*}{$\begin{array}{l}\text { Sarawak } \\
\text { Conservation } \\
\text { Program }\end{array}$} & \multirow{3}{*}{$\begin{array}{l}\text { With the support of WWF and Forest Department } \\
\text { Sarawak, one Forest Management Unit (FMU) has } \\
\text { committed to set aside } 11,600 \text { ha as orangutan } \\
\text { habitat and conservation area, where no logging } \\
\text { activities will be carried out. In another FMU } \\
\text { known as Kubaan-Puak, the FMU holder has } \\
\text { committed to implement High Conservation Value } \\
\text { (HCV) management and monitoring of important } \\
\text { wildlife connectivity area. Since } 2016 \text {, the state } \\
\text { government has gazetted a total area of } 903,769 \text { ha } \\
\text { comprising } 43 \text { national parks, } 14 \text { natural reserves, } \\
\text { and } 6 \text { wildlife sanctuaries. In addition, Batang Ai } \\
\text { National Park, Ulu Sebuyau National Park, Sedilu } \\
\text { National Park, and Lanjak Entimau Wild Life } \\
\text { Sanctuary, have now been designated as Totally } \\
\text { Protected Areas (TPAs) to protect them from any } \\
\text { form of commercial exploitation. [FMU is a timber } \\
\text { concession where selective logging is performed in } \\
\text { natural forest based sustainable forest } \\
\text { management practices]. }\end{array}$} \\
\hline & $\begin{array}{l}\text { WWF facilitated the promotion of ecotourism } \\
\text { through the adoption of Ecotourism Development } \\
\text { Roadmap for the Kapuas Hulu District that also } \\
\text { features the Betung Kerihun National Park (BKNP) } \\
\text { and Danau Sentarum National Park (DSNP). }\end{array}$ & & \\
\hline \multirow{3}{*}{$\begin{array}{l}\text { East and North } \\
\text { Kalimantan } \\
\text { Program }\end{array}$} & $\begin{array}{l}\text { WWF supported environmental conservation of } \\
\text { the Kayan Mentarang Landscape, the promotion of } \\
\text { Green Economy Development in the Upper } \\
\text { Mahakam Landscape, and the protection of Borneo } \\
\text { Pygmy Elephants and Sumatran Rhino. }\end{array}$ & & \\
\hline & $\begin{array}{l}\text { WWF worked with various government agencies } \\
\text { and oil palm plantation developers in the North } \\
\text { Kalimantan province to protect the elephant and } \\
\text { rhino habitats through the adoption and } \\
\text { implementation of the Elephant } \\
\text { Conservation plan. }\end{array}$ & & $\begin{array}{l}\text { Forest Department Sarawak (FDS) has added } \\
\text { 10,000 ha peat swamp forest protected through } \\
\text { Maludam National Park extension. }\end{array}$ \\
\hline & $\begin{array}{l}\text { WWF supported (i) capacity building on GIS } \\
\text { application on conservation for government } \\
\text { agencies, (ii) public consultation of the } \\
\text { Kayan-Mentarang National Park zoning system in } \\
\text { the two districts of Malinau and Nunukan with the } \\
\text { view to strengthen park management and zonation } \\
\text { through collaborative management, (iii) } \\
\text { collaboration with NGOs and local community to } \\
\text { promote environmental stewardship based on } \\
\text { conservation and sustainable land use practices. }\end{array}$ & & $\begin{array}{c}\text { WWF in collaboration with Forest Department } \\
\text { Sarawak and Ministry of Tourism Sarawak } \\
\text { supported the promotion of ecotourism to enhance } \\
\text { the socioeconomic progress of the local } \\
\text { community. }\end{array}$ \\
\hline
\end{tabular}

Source: [4,18,19].

\section{The Heart of Borneo: The Status Quo}

Yet, despite the all-encompassing environmental initiatives and impressive accomplishments indicated in Table 3, above, the overall ecological integrity of the HoB environment has in fact worsened, and new environmental threats and challenges continue to emerge. It seems that the political will for environmental conservation has been overshadowed by the economic priority for resource exploitation. This is reflected by various resource-based economic activities flourishing in the $\mathrm{HoB}$ region that are environmentally destructive; these are systematically examined below.

\subsection{Logging Activity}

One of the significant threats to the environmental sustainability of the HoB is the legal conversion of forests into timber concessions [20]. Notably, approximately 4.4 million ha of the HoB forests in Indonesia are inside active logging concessions [21]. For example, about 900,000 ha of the remaining lowland forests of West Kalimantan in the Arabela Landscape are allocated for commercial logging purpose [22]. Another 1.8 million ha are demarcated as productive forests for future logging use. Also, there are 20 logging concessions issued across the Mahakam River Ulu district in the HoB-East Kalimantan [13]. Furthermore, $32 \%$ of the remaining 410,000 ha of the HoB carbon-rich peat swamp forest, mainly around Danau Sentarum National Park, are also categorized within the logging concession boundary [21]. In particular, in the Danau Sentarum National Park (a Ramsar 
Site), 100,000 ha of the carbon-rich peat swamp forests in the forest interior-a unique habitat for many endangered species—were lost between 2007 and 2012 [3].

Table 3. Making Sense of the Heart of Borneo Environmental Values: The Indigenous Ways.

\begin{tabular}{|c|c|}
\hline $\begin{array}{l}\text { Category of Value Embedded in the } \\
\text { HoB Environment as Deduced Based } \\
\text { on Interviewees' } \\
\text { Reasponses/Environmental Reasoning }\end{array}$ & Indigenous Interview Responses/Environemntal Reasoning \\
\hline Traditional value & \multirow{11}{*}{$\begin{array}{l}\text { ALL unanimously concurred that they are bonded by custom or adat to champion environmental } \\
\text { stewardship (traditional, cultural, social, moral, stewardship, self-transcendence value). The } \\
\text { stewardship or transcendence act of environmental conservation (conservation value) is further } \\
\text { underpinned by the belief in altruism (altruistic value), that is, an ethic of care for the benefit of future } \\
\text { generations (option, bequest value). Practically all refused to recognize any tradeoff between their } \\
\text { forest resources and money because they consider these environmental assets as their cultural identity } \\
\text { (cultural value). All also concurred that they owe a moral responsibility to their ancestors to protect } \\
\text { them at all costs (ancestral, moral value). }\end{array}$} \\
\hline Cultural value & \\
\hline Social value & \\
\hline Moral value & \\
\hline Stewardship value & \\
\hline Self-transcendence value & \\
\hline Conservation value & \\
\hline Altruistic value & \\
\hline Option value & \\
\hline Bequest value & \\
\hline Ancestral value & \\
\hline Ancestral value & \multirow{6}{*}{$\begin{array}{l}\text { ALL the local communities show due respect and passion toward their ancestral land and forests, } \\
\text { which they considered as the home of their forefathers (ancestral value, sense-of-place value), as well as } \\
\text { the base of their socioeconomic sustenance (instrumental, self-enhancement value) and cultural identity } \\
\text { (cultural value). In other words, ancestral land and forests that connect them with the ancestral past } \\
\text { provide them with social, spiritual and cultural distinctiveness. Some believed that their ancestor } \\
\text { spirits sometimes returned to their village to rest and take care of their children (spiritual value). }\end{array}$} \\
\hline Sense-of-place value & \\
\hline Instrumental value & \\
\hline Self-enhancement value & \\
\hline Cultural value & \\
\hline Spiritual value & \\
\hline Psychological value & \multirow{4}{*}{$\begin{array}{l}\text { ALL those who have traveled to the town areas feel that they are psychologically happier } \\
\text { (psychological value) and aesthetically pleased (aesthetic value) living in the forests than in the town } \\
\text { because the forested environment gives them a sense of belonging (existence, sense-of-place value), } \\
\text { peacefulness, and their original home to which they belong (psychological, sense-of-place value). }\end{array}$} \\
\hline Aesthetic value & \\
\hline Existence value & \\
\hline Sense-of-place value & \\
\hline Existence value & \multirow{2}{*}{$\begin{array}{l}\text { ALL embrace the moral fold of cultural sustainability that is premised on the continued existence of } \\
\text { ancestral land and forests through inheritance (existence value). All also considered that they belong to } \\
\text { nature and form a part of it (environmental value). }\end{array}$} \\
\hline Environmental value & \\
\hline & $\begin{array}{l}\text { Methodological (deductive) approach (an illustration): Taking the indigenous custom which requires all } \\
\text { the local people to protect their environment so that the future generation will be able to enjoy the same } \\
\text { ecologically integrated environment as enjoyed by the present generation (bequest motivation), we can } \\
\text { infer a range of values associated with this customary act of obedience }\end{array}$ \\
\hline
\end{tabular}

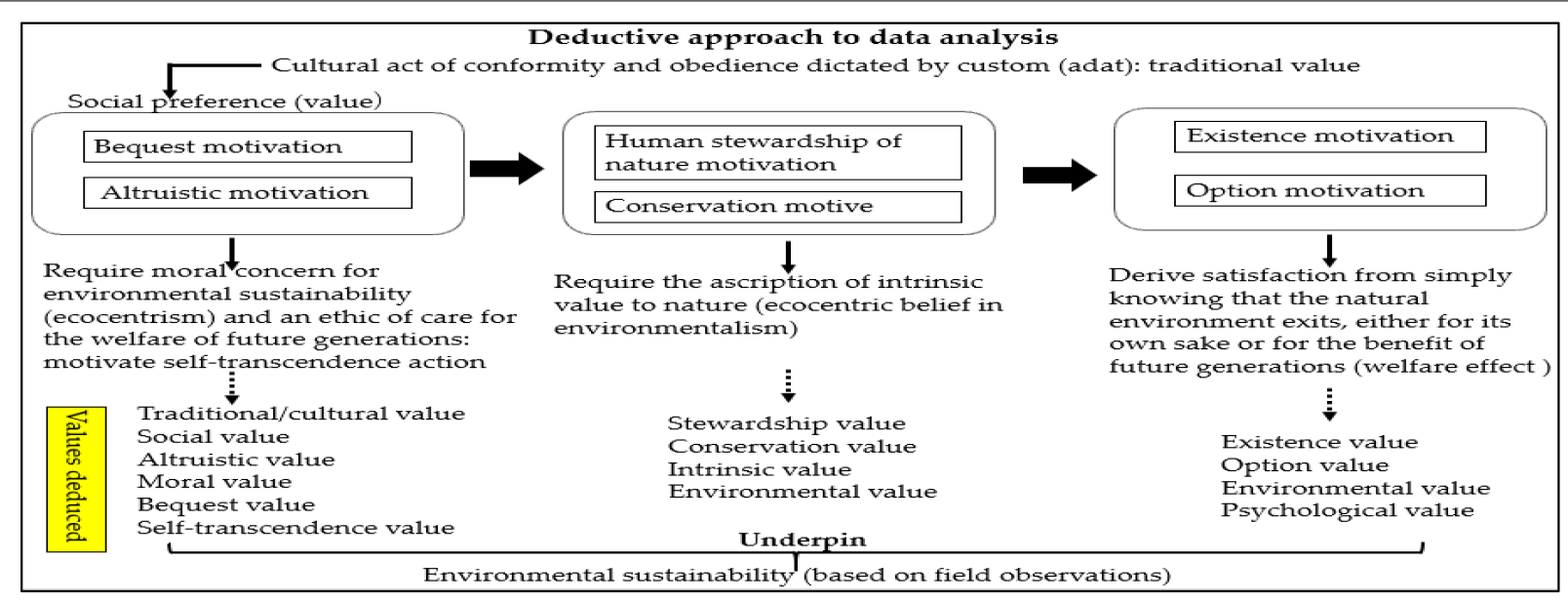

Note: It is practically impossible to draw a clear line representing the degree of importance for the contributing role of the pluralist range of values, as shown in the Table, that map precisely to the overlapping environmental motivations and behaviors of the local people. All these values are equally interconnected and mutually enforcing or at times competing. 
In addition, the upper Seruyan area in the southwestern part of HoB in Central Kalimantan is identified as one of the areas with a high level of forest conversion and fragmentation due to rampant timber harvesting as well as widespread oil palm plantation development $[22,23]$. Furthermore, the areas surrounding the Mahakam River and its tributaries have been heavily logged. All the lowland forests in the Kutai Barat district have also been heavily depleted, and timber harvesting is rapidly expanding to the uplands [22,24,25]. Indeed, the forests in Kutai Barat district decreased persistently from 1990 to 2010, with an area of 1.24 million ha in 2000, 1.1 million ha in 2005, and 952,000 ha in 2010 [24].

In Sarawak, logging concessions also covered the HoB conservation areas adjacent to Bentuang Karimun National Park to the south in Kalimantan and the Lanjak Entimau Wildlife Sanctuary to the west in Sarawak (the Sarawak-West Kalimantan Transboundary Landscape). This endangers the continued survival of many wildlife species, including more than one thousand orangutans thriving in the protected wildlife sanctuary in Sarawak. It has been reported that about 1000 ha of forests have been logged illegally in the region [26]. Furthermore, logging concessions have also been extended to part of the Danum Linau National Park, demarcated within the Brunei-Sabah-Sarawak-North Kalimantan Transboundary Landscape. This is illustrated by the extensive damage caused to the previously intact rainforest canopy in the park $[27,28]$. Logging also occurred around Mulu National Park in the same transboundary landscape [2,21]. It is thus increasingly clear that the $\mathrm{HoB}$ forests, $\mathrm{HoB}$ trilateral landscapes, and national parks are not safe from human economic pressure despite putting in place various environmental conservation plans or legal instruments.

\subsection{Monoculture Development: Oil Palm Plantation Expansion}

Indonesia and Malaysia are two of the world's largest palm oil exporters. Both countries together account for 85 percent of global palm oil production, with Indonesia positioned as the largest global palm oil producer [29]. Both countries consider industrial oil palm development as one of the strategic means to promote economic sustainability and social equity in terms of increased export earnings and poverty reduction through employment opportunities and improved income [30]. Since 2005, Indonesia and Malaysia have been rigorously promoting commercial-scale oil palm plantation development in the transboundary frontier between Kalimantan and Sarawak and Sabah, impacting the ecological integrity of the HoB [13].

Over the past few decades, many natural forests that lie within the HoB region in both countries have been cleared for oil palm plantation development [31]. For example, between 2007 and 2012, about 45,500 ha of the Indonesian HoB-forest categorized as "Areal Penggunaan Lain" (Other Land Use) was converted into oil palm or commercial tree plantations. Most of this occurred in West Kalimantan, leading to a high level of forest fragmentation [21,22]. Furthermore, nearly all of the western part of the HoB, particularly the area west of Danau Sentarum National Park, situated in areas of the carbon-rich peatswamp forest and embedded within the Muller-Schwanner-Arabela Landscape, has been severely deforested and fragmented due to the expansion and intensification of oil palm plantation development $[22,32,33]$. This exerts immense pressure on the continued survival of the Bornean orangutans and the proboscis monkeys, as well as a vast range of other endemic and rare species that thrive in the park [34-37].

In addition, more than 322,000 ha, an area twice the size of London, have been deforested in the Barito River watershed over the past ten years due to commercial land conversions, especially for oil palm plantation development. According to the Indonesian Space Agency LAPAN, in total, about 650,000 million ha (14 percent) of Barito's watershed (4.5 million ha) are covered with plantations [38]. Large tracts of forests close to the HoB-Danau Sentarum National Park were also cleared for oil palm cultivation [39].

The increased expansions of oil palm plantation development in areas around Sarawak's Batang Ai National Park and Lanjak-Entimau Wildlife Sanctuary, which borders West 
Kalimantan's Betung Kerihun National Park, and in upper Balui sub-watersheds in the biodiversity-rich HoB-Rajang Basin, are increasingly threatening the ecological integrity of the HoB [21,40]. In addition, the upper Balui sub-watersheds in the biodiversity-rich HoBRajang Basin are highly fragmented due to the extensive conversion of forest landscapes into other land uses, such as oil palm cultivation, between 2007 and 2010 [21]. Besides, the UNESCO-protected Gunung Mulu National Park in Sarawak embedded in the HoB, is increasingly exposed to the potential threats of environmental degradation due to the expansion of a 4,400 ha-palm oil development plan in its vicinity [41].

In Sabah, the HoB-DaMaI (Danum Valley, Maliau Basin, and Imbak Canyon) demarcated within the Crocker Range-Central Forest Landscape was under siege by the development of 80,000 ha of oil palm plantations within the protected areas $[21,42,43]$. The Kinabatangan watershed originates from the interior mountains of the Maliau Basin in the HoB landscape and is highly fragmented due to extensive commercial land conversion especially oil palm plantation development. This threatens the continued survival of the Sunda Clouded Leopard, which thrives in the region $[3,44,45]$. Furthermore, an estimated one million cubic meters of timber is smuggled out of the HoB area each year, leaving a destroyed forest region [46]. Interestingly, the deforestation rates in the HoB increased between 2007 and 2012, resulting in the loss of some two million ha of forests since the official inception of the HoBI in 2007 [20,21].

It is thus clear that monoculture development constitutes one of the biggest drivers of deforestation in the HoB region in Indonesia Kalimantan and Borneo Malaysia, threatening the ecological integrity of the HoB.

\subsection{Mining Activity}

The mining industry in Borneo poses another threat to the ecological health of the $\mathrm{HoB}$ [22]. Much of the mining in Borneo is for coal [47]. In Borneo, approximately 4.5 million ha of forests are under mining concessions, and almost half of this is within the HoB. Nearly one quarter (about 838,000 ha) of the remaining HoB's lowland rainforest area and 853,000 ha of the HoB's upland rainforest are inside mining concessions [21]. In Kalimantan, practically all mining concessions are issued for coal [48]. Indeed, the coal mining industry is now moving rapidly to the forests of Central Kalimantan and the Mueller Mountains, where large coal deposits have been found in the Barito River basin [49,50]. As of 2016, over 20\% (3.7 million ha) of land in Central Kalimantan were allocated for coal exploration and mining and approximately $66 \%$ of the mining concessions are in the Barito River basin [48].

One of the largest players in the coal mining industry is BHP Billiton. Its project, known as the IndoMet Project, spans an area of 350,000 ha, including 75,000 ha of undisturbed primary forests in the heavy-forested Barito River basin in the remote HoB region-a mega-diverse and world-renowned forest ecosystem that is home to large populations of orangutans and many other yet-to-be-discovered species [51,52]. The Barito watershed is also a life support system for thousands of indigenous people.

Compared to Indonesia, Malaysia has a very small coal mining sector, which is almost wholly based in Sarawak. The bulk of the production occurs in the Merit Pila coalfield upstream of Kapit, which lies within the HoB boundaries [15]. This can be environmentally destructive to the ecological integrity of the five million ha, biodiversityrich Rajang River Basin.

\subsection{Infrastructure Development}

Infrastructure development in Borneo also represents one of the gravest threats to the ecological resilience of HoB. For example, the planned and ongoing Trans-Kalimantan Highway project in Kalimantan would intersect 25 existing protected areas that are currently free from major road incursions, leading to extensive disturbances in forest connectivity. The affected regions include the Kayan Mentarang National Park in the Brunei-Sabah-SarawakNorth Kalimantan Transboundary Landscape, and the Bukit Baka-Bukit Raya National 
Park in the Muller-Schwaner- Arabela Landscape of West and Central Kalimantan [22,53]. In Borneo Malaysia, the construction of the Pan Borneo Highway $(\mathrm{PBH})$ that cuts through the biodiverse HoB will lead to widespread environmental disturbances. In particular, the project is expected to negatively impact the Lanjak Entimau Wildlife Sanctuary, which lies within the HoB boundaries.

The forest connectivity of the HoB wildlife corridors is further worsened by the development of a series of mega-dam projects in Sarawak. This includes the completed Bakun dam (69,640 ha) and Murum dam (24,500 ha), and the ongoing Baleh dam located in the upper Rajang River Basin [54,55]. In all, the state government plans to construct 12 dams in the forested areas for economic reasons [55]. These dam projects, when completed, will affect the forest connectivity and wildlife habitats of Batang Ai National Park, Gunung Mulu National Park, Baleh National Park bordering the Sarawak and Kalimantan Mountain ranges, and the Lanjak Entimau Wildlife Sanctuary in the Bakun-Murum dam region that lies within the HoB boundaries [53].

\section{The Breakdown of the Heart of Borneo Environmental Conservation System: The Problem of Monist Valuation}

To be sure, the HoB environmental protection plans and strategies heretofore discussed meet all the criteria of environmental sustainability. However, their implementation processes failed to proceed effectively, as expected of them. This is attributed to the argument that the political will for real enforcement has ultimately been hampered by the paramount objective of economic maxima. In other words, the HoB natural environment is, to a large extent, perceived for its economic benefits (instrumental value) derived from timber harvesting, oil palm plantation development, coal extraction, and other incidental development such as infrastructure development.

Put differently, the normative judgments for environmental conservation in the $\mathrm{HoB}$ region are heavily influenced by economic considerations of the instrumental values nature offers to people. This is an expression of the importance of economic relationships that the people hold with the HoB environment. The economic optimization of nature in protected areas, such as the Muller Mountain Range in Central Kalimantan, Batang Ai National Park, and Lanjak-Entimau Wildlife Sanctuary in Sarawak and HoB Damal in Sabah, as discussed above, are some of the obvious examples of such relationships. That said, the economic value orientation indicates and explains the causes of ecological degradation of the HoB environment. This is in part due to the lack of clear understanding and enhanced information on the part of the policymakers concerning a diverse range of values embedded in the HoB environment. Thus, the HoB natural systems are still vulnerable to human economic intervention despite putting in place a comprehensive set of local and trilateral protected area management practices, environmental laws, and regulations.

Here, the regional policymakers are skewed toward embracing an anthropocentricecocentric behavioral orientation, defined as the overly strong tendency to instrumentally optimize the economic benefit of nature without giving equal or sufficient weight to the ethical concern for environmental protection. When conflicts arise between economic and environmental interests, the former will take precedence over the latter. Notably, anthropocentrism literally means human-centered and is associated with exploitative attitudes and behaviors toward the natural environment. It signifies that the way sustainability is conceived is heavily influenced by the instrumental values people place on nature. Ecocentrism is Earth-centered and is associated with the moral concern for environmental protection [2].

To break the above impasse, we attempt to construct a typology of value embedded in the HoB environment to guide political decisions in the economic use of nature, which is ecologically congenial, economically viable, socially sustainable, and culturally desirable in the long run; this will be examined in the following section. 


\section{Making Sense of the Heart of Borneo Environmental Values: A Pluralistic Approach}

As noted in Section 4, one of the major aims of HoBI is to improve the social welfare of the local people (social sustainability) based on sustainable resource use and management (environmental sustainability). Despite this, nonetheless, practical politics is easier said than done. As discussed above, resource use practices are still heavily guided by the ethics of anthropocentrism, where economic growth is highly preferred compared to environmental conservation. This is basically due to a lack of clear understanding of the diversity of HoB values associated with the local people's social and cultural beliefs, which is equally important in contributing to enhancing their social welfare.

In this section, we attempt to make sense of the diverse range of values embedded in HoB to aid policymakers to match social and cultural needs to political choice of development. While Section 9.1 focusses on the evaluation of values associated with the customary beliefs (adat) of the local people, Section 9.2 deals with HoB ecosystem life-supporting values that contribute to promoting environmental sustainability-an indispensable component of economic and social sustainability.

\subsection{Values Associated with Indigenous Customary Beliefs (Adat-or Custom-Based Values)}

The HoB environment has a range of diverse values apart from its economic value, as largely embraced by the policymakers. Fieldwork and face-to-face interviews conducted with 827 indigenous people revealed that there are non-quantifiable HoB environmental values that are equally important in contributing to enhance their social welfare (social sustainability) - one of the HoB green objectives. These HoB values, which are interlapping, mutually reinforcing, and at times competing, are shown in Table 3.

With reference to Table 3 , in contrast to the policymakers who largely viewed the environment for its instrumental value, the local people accord it with a variety of values based on their customary beliefs, environmental worldviews, and socio-economic needs. The diversity of these value orientations reflects the importance of the specific cultural, environmental, social, and economic relationships these people hold with the environment.

From the economic perspective, the local people treat the HoB environment (land and forests) as a means to an end; that is, it has instrumental value to support socio-economic sustenance (instrumental value, self-enhancement value). Such use mainly covers the economic exploitation of nature in the form of farming such as swidden agriculture, hunting and gathering, and wood extraction, among others, to satisfy their daily needs. Notably, self-enhancement value is exemplified by the pursuit of self-interest (instrumental value).

However, the local people are bound by their custom known as adat to exercise certain forms of self-restraint in the economic use of nature so as not to cause aggressive, extensive, and irreversible destruction of the natural environment [1,2]. This serves to protect the intrinsic value of nature. Here, the local people embrace quasi-Earth-centered or ecocentric-anthropocentric environmental behavior. Intrinsic value may be defined as the value nature has in itself, for its own sake or for its own existence, while ecocentrism places heavy emphasis on the protection of the intrinsic value of nature.

Viewed from cultural and social perspectives, the local people consciously or unconsciously endorsed different values based on their customary environmental belief systems (adat or custom). These values can be in conflict or overlap with each other, deepening the priority or preferences the local people give to specific man-nature relations that they considered culturally desirable or socially important. As a case in point, the local communities are culturally, socially, and morally required by adat (social, cultural, traditional, and moral values) to protect their lands and forests (conservation or stewardship, existence, and self-transcendence values) when optimizing their economic use for the benefit of future generations (bequest value) [1,56]. Self-transcendence value is exemplified by a concern for the welfare of other people in connection with social justice, equality, and care for nature. This is to ensure that their descendants will inherit an option (option value) to enjoy an ecologically healthy environment, as enjoyed by the current generations (bequest value). 
This cognitive action of conformity and obedience to the tribal custom of caring is grounded in their traditional value preference to maintain and sustain their centuries-old man-nature relationships as well as the aesthetic beauty of the natural surroundings (environmental, traditional, and aesthetic values). From this act of conformity and obedience, the local people derive a psychological sense of satisfaction and happiness (psychological value).

The ethical reasoning behind the above value-laden environmental practices may be traced back to the traditions of indigenous people in Borneo. To emphasize, the natural environment or customary land and forests symbolically link the local communities with their ancestral past (ancestral value). They provide a traditional bond between the dead or the ancestors (spiritual value) and the living or the present generation as well as the yet to be born future generation (kinship and sense of place values) [56]. Thus, the local people are duty-bound to observe the biophysical limits to the instrumental use of nature, based on sustainable resource use management. Psychologically, the local people are also satisfied in honoring their inter-generational moral obligations toward their ancestors (ancestral value) and future generations, as this contributes to enhance their wellbeing (psychological value).

To sum up, the indigenous conscious or unconscious endorsement of value pluralism exhibits a remarkable moral force to induce a strong ethic of environmental conservation (ecocentrism) when optimizing the instrumental value of nature (anthropocentrism), thus, drawing a balance between environmental exploitation and ecological conservation. More specifically, the pluralist range of values embedded in the indigenous adat contribute to stimulate the local people toward embracing an ecocentric or Earth-centered model of relationship with nature-the core basis of environmental sustainability. Based on field observations, the indigenous environmental belief systems and the endorsement of value pluralism have enabled them to protect and conserve their natural landscapes for the past few centuries.

It is thus clear that the preference for a specific relationship with the natural environment is a function of values that stakeholders consciously or unconsciously perceive or assign to nature. In other words, social and environmental sustainability is embedded in value-laden situations in which decisions are made when optimizing the economic use of nature, and value pluralism correlates with ecological action and environmental sustainability. Put differently, there is a positive correlation between value pluralism, environmental sustainability, and social sustainability.

\subsection{The Heart of Borneo Life-Supporting Values}

As mentioned in Section 4, the HoB is the only key watershed that supports the life of the people in the island. Endowed with tracts of carbon-rich environment, it also serves a critically important function in regulating local, regional, and global warming. As illustrated in Figure 4, the HoB system provides two important ecosystem services besides its provisioning function; that is, regulating and supporting functions that directly or indirectly underpin all forms of socio-economic activities and human long-term existence (life-supporting values). Many of these values are unquantifiable.

The protection and conservation of these life-supporting values (environmental sustainability) are crucially important to ensure that the HoB environment continues to provide these critical services to support social and economic sustainability. That said, human environmental disruptions that will adversely impact ecosystem functions will result in a range of environmental repercussions, such as global warming and extreme weather conditions, which are detrimental to long-term socio-economic prosperity and human existence [57]. 


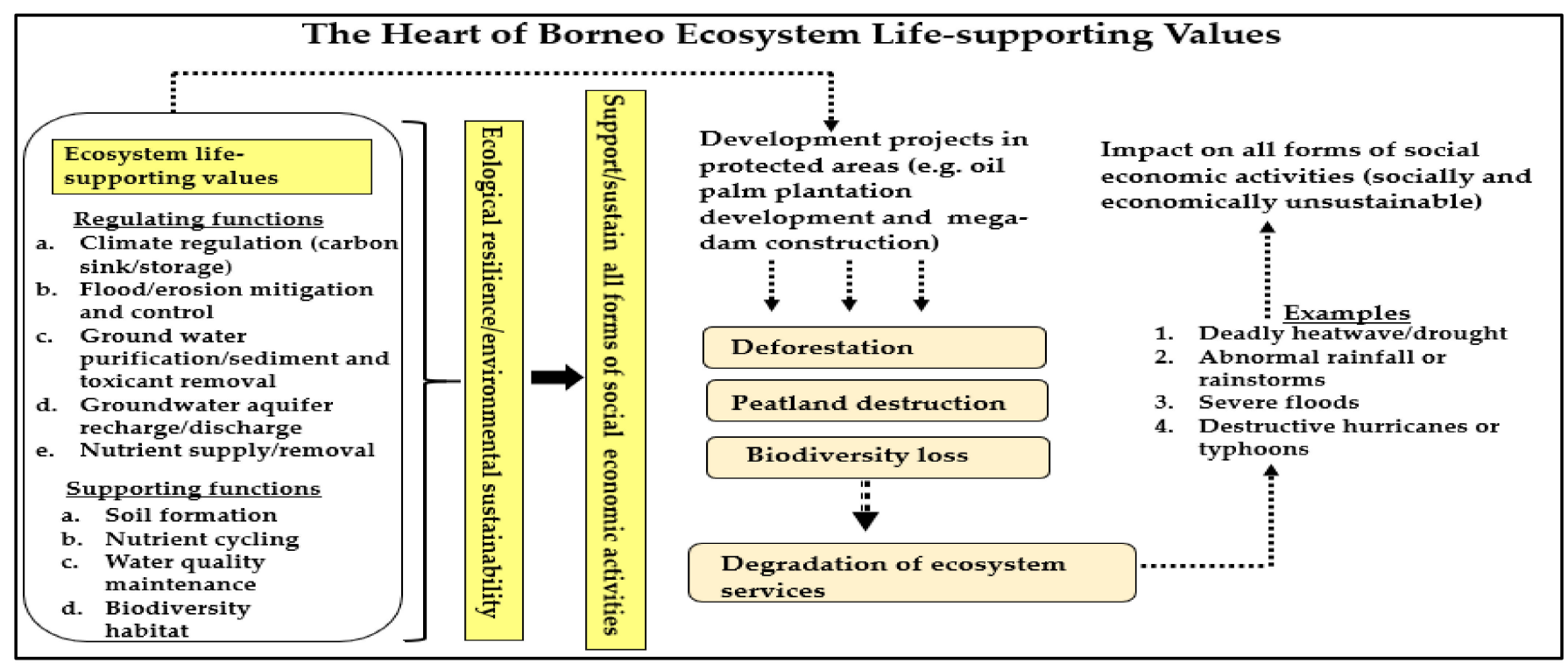

Figure 4. Life-Supporting Values of the Heart of Borneo Natural Systems.

In light of the above, admittedly the HoB forests store substantial amounts of terrestrial carbon in their trees. For example, the peat swamp forests of Central Kalimantan store the largest amount of carbon in Borneo, approximately 6.4 Gigatons with an economic value ranging from a minimum of USD 500 million and a maximum of USD 7.1 billion [58,59]. In a recent study, it was reported that unlogged intact HoB forests in the state of Sabah contain aboveground carbon densities averaging over 200 megagram of carbon per hectare, with peaks of 500 megagram of carbon per hectare. This exceeds the carbon stocks of most tropical forests [60]. Thus, the HoB is endowed with one of the most critical global green lungs in regulating global warming or climate change, and conserving its ecological resilience is undoubtedly one of the most important agendas of global environmental sustainability.

Further, regulating and supporting services (Figure 4), as provided by the HoB environment, are crucially important in supporting the life of approximately 11 million people in Borneo. In particular, about one million indigenous forest-dwellers depend directly on HoB's provisioning, regulating, and supporting services for socio-economic sustenance and cultural practices. Thus, conserving and protecting the life-supporting values (environmental sustainability) of the HoB is critically important to ensure social and economic sustainability.

In support of the above revelations, it may be demonstrated that human-induced peatland forest degradation in Indonesia, especially in the HoB region, involving the development of the Indomet project as discussed above, has contributed to aggravating the intensity of various disasters such as floods and drought in the country. For the past five years, since 2014, the extent of these disasters has increased from 1967 to 3721 cases in 2019 nationwide. This includes the recent record-breaking rainfall equivalent of 72,000 Olympicsize swimming pools that battered across Jakarta in January 2020 [61].

In addition, coal mining in the upstream of the Indonesian coal capital Samarinda has resulted in severe flooding in the region. Deforestation caused by the mining industry in the region has impacted the regulative capacity and supporting function of the upstream ecosystems to absorb rainwater, causing massive volumes of runoff to gush into the Mahakam River, resulting in serious flooding in the city. Between 2008 and 2009, major floods that occurred in the city disrupted the economy, transportation, employment, and livelihoods of the local people, resulting in an economic loss of USD 9 million. It has been reported that the cost of flood prevention is far greater than the town's income from coal. For example, the proposed flood mitigation plan alone would cost a whopping USD 350 million [3]. The social and economic destructive transboundary haze pollution spread from Kalimantan to Indonesia's neighboring countries in Malaysia, Singapore, Thailand, 
and the Philippines as a result of widespread peatland destruction, caused by commercial land conversions in Kalimantan, also offers a good illustrative example [2].

It is increasingly clear that the $\mathrm{HoB}$ is embedded in a diverse range of values as summarized in Figure 5: (i) the economic or instrumental value (economic-based), as anthropocentrically embraced by economic planners, (ii) a variety of hard-to-define cultural values, as reflected in the indigenous customary environmental belief systems (adatbased), and (iii) the life-supporting values in connection to the provision of ecosystem services (environment-based), which underpin all forms of socio-economic development. Thus, the HoB should be assessed qualitatively in biophysical terms using natural science and culturally based on a human-nature philosophical study of their values to support not only economic and social sustainability but also, most importantly, environmental sustainability-the most critical component of all forms of sustainability.

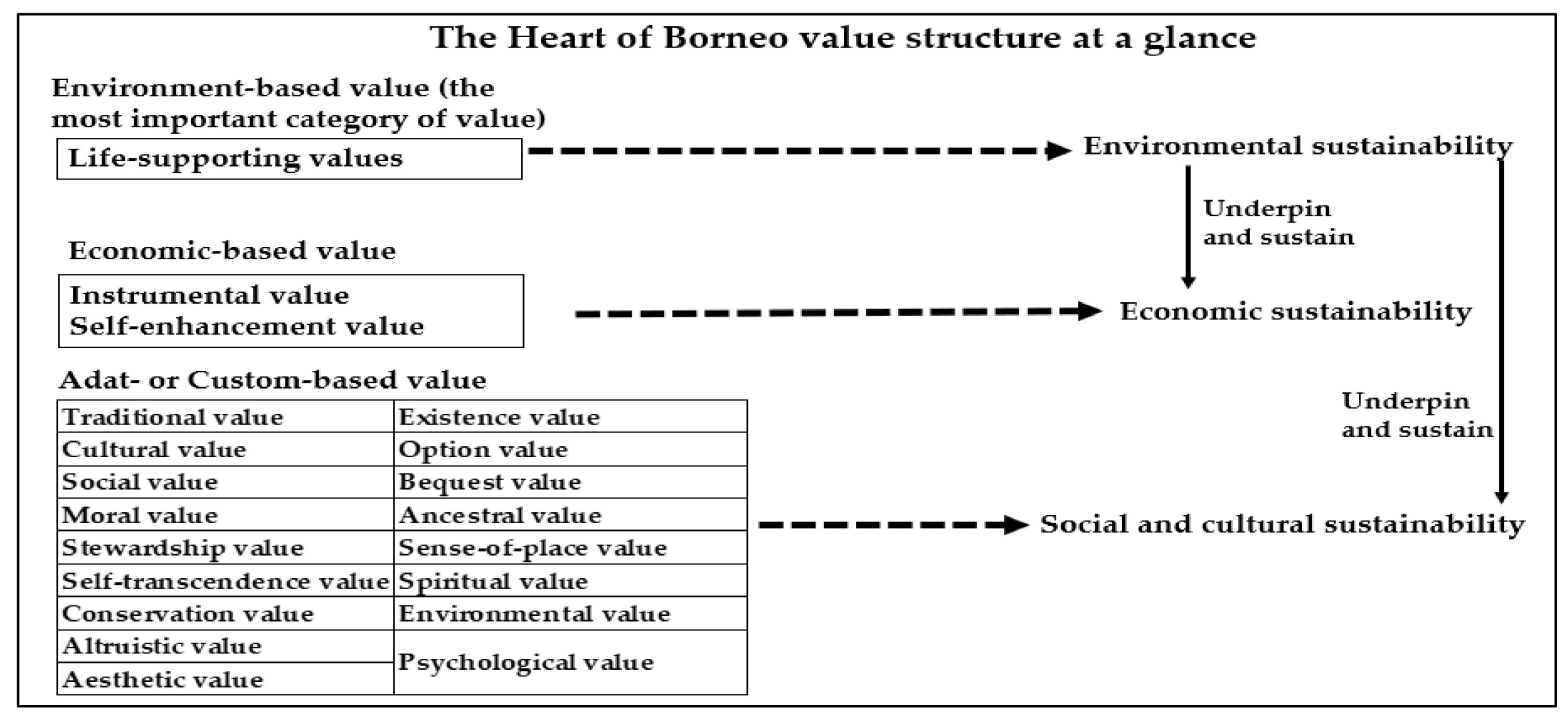

Figure 5. The Heart of Borneo Value Structure: Summary.

Finally, it is important to reiterate that the interplay of all the above nature-based values, competing and overlapping, contributes collectively to fostering environmental, economic, and social sustainability. Although it is particularly challenging to express the monetary worth of cultural values directly or meaningfully, as they are not reflected in market prices, their conservation has considerable potential for enhancing social welfare and quality of life for the local people, as discussed above.

\section{The Heart of Borneo Green Economic Transformation: The Way Forward}

Based on the above observations, human-induced environmental disruptions involving large-scale interventions in ecosystems must be avoided, particularly if such development projects involve environmental impairment or irreversible destruction of massive biologically sensitive and ecologically diverse HCV natural systems. Under these circumstances, even if it is difficult or impossible to determine the ecological threshold levels, the precautionary principle should apply, and unsustainable environmental exploitation must be suspended [2]. The precautionary principle requires that "where there are threats of serious or irreversible damage, a lack of full scientific certainty shall not excuse States from taking cost-effective measures to prevent environmental degradation" [62].

In other words, it is necessary to forgo the pursuit of the monist dimension of economic value in favor of pluralist environmental interests in order to enhance the green concept of development genuinely. However, this does not imply that the instrumental exploitation of natural systems in Borneo should be completely halted. Instead, it signifies the application of the ethics of care (ecocentrism) when optimizing the economic use of nature in ways that avoid massive and irreversible destruction of biologically sensitive or critical ecosystems. 
This brings us back to the fundamental issue of the need to conserve the existence, bequest, and option values of the natural environment in consonance with the main line of thought of the indigenous environmental belief systems. This will ensure that the natural environment continues to provide a range of economic, social, and cultural benefits for the betterment of mankind. This characteristic view of value pluralism should serve as a recognition of the need to follow the precautionary principle when optimizing the economic use of nature.

Thus, oil palm plantation development in protected area and carbon-rich peatlands or forests must be avoided. To reinforce environmentally sustainable development, illegal logging and illegal cross-border timber trade must be strictly regulated and controlled by putting in place well formulated measures guided by value judgements in a credible fashion. In view of the growing realization of the magnitude of environmental disruptions involving the development of mega-infrastructure projects, full conviction must be given to ensure that their development does not result in irreparable or irreversible diversions and destructions of biologically sensitive and critically protected natural environments.

The rationale behind this environmental compliance is that many of the environmental consequences arising from irreversible destructions of critical natural environments are cumulative in character, in that their potential real effects will come to light only by accumulation over long periods. By then, it may be too costly or impossible to address them effectively, thus threatening man's long-term existence. Implicitly, the overriding consideration is to protect the multiple values embedded in nature. This is substantially compatible with the regional green economic transformation discourse, as originally envisaged. In a nutshell, sustaining long-term green development depends more on the strategic non-economic elements (environmental values/ecosystem services) compared to the economic factors (economic values/factors of production).

\section{Conclusions}

The endorsement of instrumental value is the most common practice in the economic tradition of valuation involving environmental development projects. This is partly due to the lack of a clear understanding of the plurality of nature values and the interplay of these values that ensure sustainable socio-economic development. Drawing from a case study in the Heart of Borneo, the present study contributes to a greater understanding of the long-standing intellectual deficiency regarding the values of nature and their contributions to environmental, economic, and social sustainability. In particular, it furnishes a typology of value concepts and the associated empirically tested environmental worldviews that help to guide green development decision-making from a long-term perspective.

The Heart of Borneo case study sheds light on the current unsustainable development practices driven by the ethics of anthropocentrism with the monist view of optimizing the instrumental use of nature. The value preference for this monist dimension of resource use practice (value monism) constitutes an expression of the importance of economic relationships (means-ends relationship) that people hold with non-human nature. Such an anthropocentric perception of nature, partly caused by an inadequate understanding of the interplay of nature values, significantly induced man's deeper encroachment into the Heart of Borneo protected environment to maximize its short-term economic gains while paying inadequate attention to the long-term aspects of socio-economic development.

This instrumentalized environmental thought process has resulted in significant adverse impacts on long-term green development in the region. More specifically, it serves not only to impede the momentum of growth as originally planned, but also leads to social disruption and welfare loss arising from the degradation of ecosystem services. That said, environmental degradation in the Heart of Borneo will continue to occur, despite putting in place a myriad of protected area management policies and practices, without a change in behavioral and value orientations that skew towards the ethics of ecocentrism and the endorsement of nature-based value pluralism. 
Author Contributions: Both authors contributed equally to their workloads for the paper. All authors have read and agreed to the published version of the manuscript.

Funding: This research was funded by JSPS KAKENHI, grant number $18 \mathrm{H} 03429$.

Institutional Review Board Statement: Not applicable.

Informed Consent Statement: Not applicable.

Data Availability Statement: Not applicable.

Acknowledgments: This work was partly supported by JSPS KAKENHI Grant Number 18H03429. Any opinions, findings, conclusions, or recommendations expressed in this material are those of the author(s) and do not necessarily reflect the views of the author(s)' organization, JSPS, or MEXT. The authors are grateful to two anonymous reviewers for their insightful comments and suggestions for improvement.

Conflicts of Interest: The authors declare no conflict of interest.

$\begin{array}{ll}\text { Abbreviations } \\ \text { HCVF } & \text { high conservation value forest } \\ \text { HoB } & \text { Heart of Borneo } \\ \text { HoBI } & \text { Heart of Borneo Initiative } \\ \text { HSAP } & \text { HoB Strategic Action Plan } \\ \text { SNAP } & \text { Strategic National Action Plan } \\ \text { TSPA } & \text { Trilateral Strategic Plan of Action } \\ \text { km }^{2} & \text { square kilometer } \\ \text { ha } & \text { hectare }\end{array}$

\section{References}

1. Choy, Y.K. Cost-benefit Analysis, Values, Wellbeing and Ethics: An Indigenous Worldview Analysis. Ecol. Econ. 2018, 145, 1-9. [CrossRef]

2. Choy, Y.K. Global Environmental Sustainability: Case Studies and Analysis of the United Nations' Journey toward Sustainable Development; Elsevier: Amsterdam, The Netherlands, 2020.

3. Van Paddenburg, A.; Bassi, A.; Buter, E.; Cosslett, C.; Dean, A. Heart of Borneo. Investing in Nature for a Green Economy; WWF HoBs Global Initiative: Jakarta, Indonesia, 2012. Available online: https:/ /wwfint.awsassets.panda.org/downloads/heart_of_borneo_ green_economy_main_report_2012.pdf (accessed on 30 March 2021).

4. WWF. Updates of the Heart of Borneo; WWF-Indonesia: Jakarta, Indonesia, 2017. Available online: https:/ / wwfint.awsassets.panda. org/downloads/updates_on_hob_programme_fa_desktop_.pdf (accessed on 30 March 2021).

5. Lim, M. Strengthening the Legal and Institutional Effectiveness of Transboundary Biodiversity Conservation in the 'Heart of Borneo'. Asia Pac. J. Environ. Law 2014, 17, 65-89.

6. Alamgir, M.; Campbell, M.J.; Sloan, S.; Engert, J.; Word, J.; Laurance, W.F. Emerging Challenges for Sustainable Development and Forest Conservation in Sarawak, Borneo. PLoS ONE 2020, 15, e0229614. [CrossRef] [PubMed]

7. Perry, R.B. Realms of Value; Harvard University Press: Cambridge, MA, USA, 1954.

8. Dewey, J. Theory of Valuation. In International Encyclopedia of Unified Science; University of Chicago Press: Chicago, IL, USA, 1943; Volume 2.

9. Schwartz, S.H. Universals in the Content and Structure of Values: Theoretical, Advances and Empirical Tests in 20 countries. In Advances in Experimental Social Psychology; Zanna, M., Ed.; Academic Press: New York, NY, USA, 1992; Volume 25, pp. 1-65.

10. Kluckhohn, C. Values and Value Orientations in the Theory of Action: An Exploration in Definition and Classification. In Toward a General Theory of Action; Parsons, T., Shils, E., Eds.; Harvard University Press: Cambridge, MA, USA, $1951 ;$ pp. $388-433$.

11. Williams, R.M. Values. In International Encyclopedia of the Social Science; Sills, D.L., Ed.; Macmillan: New York, NY, USA, 1968; Volume 16, pp. 283-287.

12. Pio, D. Borneo's Lost World: Newly Discovered Species on Borneo; WWF-Indonesia: Jakarta, Indonesia, 2005. Available online: https:/ / wwfint.awsassets.panda.org/downloads/newlydiscoveredspeciesonborneo25042005.pdf (accessed on 30 March 2021).

13. FPP. Breaking the Heart of Borneo. Forest Peoples Programme (FPP): United Kingdom. 2020. Available online: https://www. forestpeoples.org/sites/default/ files / documents / Breaking-the-heart-of-Borneo-ENG-digital.pdf (accessed on 30 March 2021).

14. Forest Department Sarawak. Heart of Borneo (HoB) Initiative; Forest Department Sarawak: Sarawak, Malaysia, 2020. Available online: https: / forestry.sarawak.gov.my/page-0-146-993-Heart-of-Borneo-HoB-Initiative.html (accessed on 4 April 2021).

15. Brander, L.; Tai, B.; Yeo, B.H. Natural Capital Valuation Using Primary Data Research Methods in Baleh, Sarawak Heart of Borneo Project. WWF-Malaysia Project Report; WWF: Sarawak, Malaysia; Jakarta, Indonesia; Frankfurt, Germany, 2018. 
16. WWF. Heart of Borneo. A Paradise of Biological Wonder; WWF: Jakarta, Indonesia, 2018. Available online: https://d2ouvy59p0dg6k. cloudfront.net/downloads/hob_factsheet_2018_web.pdf (accessed on 4 April 2021).

17. WWF. Rights, Responsibilities and Resources: Thriving Environment-Wellbeing of People. Partnership Programme Report 2018 to Ministry for Foreign Affairs of Finland; WWF: Helsinki, Finland, 2018.

18. KePKAS. Sabah has Achieved Tremendous Progress in Environment Conservation through the Heart of Borneo (HoB) Initiative; Ministry of Tourism, Culture and Environment: Sabah, Malaysia, 2019. Available online: https:/ /kepkas.sabah.gov.my/inside-kepkas/sabahachieves-tremendous-progress-in-environment-conservation-through-heart-of-borneo-initiative/ (accessed on 6 April 2021).

19. Gaworecki, M. Sarawak Establishes 2.2 M Acres of Protected Areas, May Add 1.1 M More. Mongabay. 2016. Available online: https:/ / news.mongabay.com/2016/08/sarawak-announces-department-of-national-parks-and-wildlife-to-open-nextyear/ (accessed on 7 April 2021).

20. Maddox, T.M. Experience in International Cooperation on Transboundary Landscape Management from the Heart of Borneo Initiative. In Proceedings of the Fourth GMS Environment Ministers' Meeting, Nay Pyi Taw, Myanmar, 27-29 January 2015.

21. WWF. The Heart of Borneo Environmental Status Report 2014. WWF's HoB Initiative: WWF. 2014. Available online: https: / / wwf.panda.org/?220750/The-Heart-of-Borneo-Environmental-Status-Report-2014 (accessed on 7 April 2021).

22. WWF. The Environmental Status of Borneo 2016 Report; Heart of Borneo Programme: Jakarta, Indonesia, 2017.

23. Potter, L. Managing Oil Palm Landscapes: A Seven-Country Survey of the Modern Palm Oil Industry in Southeast Asia, Latin America and West Africa; CIFOR (Center for International Forestry Research): Bogor, Indonesia, 2015.

24. Zulkarnain, M.T.; Widayati, A. Forest Conversions and Degradation in Kutai Barat District, Indonesia. Brief 46. Bogor, Indonesia; Southeast Asia Regional Program; World Agroforestry Centre (ICRAF): Nairobi, Kenya, 2015.

25. Van der Laan, C.; Budiman, A.; Verstegen, J.A.; Dekker, S.C.; Effendy, W.; Faaij, A.P.C.; Kusuma, A.D.; Verweij, P.A. Analyses of Land Cover Change Trajectories Leading to Tropical Forest Loss: Illustrated for the West Kutai and Mahakam Ulu Districts, East Kalimantan, Indonesia. Land 2018, 7, 108-2018. [CrossRef]

26. Council on Ethics for the Government Pension Fund Global. Annual Report 2013; Council on Ethics for the Government Pension Fund Global: Oslo, Norway, 2013.

27. Global Witness. The Threat to a Sustainable 2020 Tokyo Olympics Games Posed by Illegal and Unsustainable Logging in Sarawak, Malaysia; Global Witness: London, UK, 2015. Available online: https://www.fairwood.jp/news/pr_ev/2015/Shin-Yang-HOB-briefing.pdf (accessed on 7 April 2021).

28. Cannon, J.C. Leading US Plywood Firm Linked to Alleged Destruction, Rights Violations in Malaysia. Mongabay. 2017. Available online: https: / / news.mongabay.com/2017/10/leading-us-plywood-firm-linked-to-alleged-destruction-rights-violations-inmalaysia/ (accessed on 8 April 2021).

29. Jong, N.H. Top Indonesian Palm Oil Developments in 2020. Mongabay. 2020. Available online: https://news.mongabay.com/20 20/12/top-indonesia-palm-oil-news-story-2020/ (accessed on 7 April 2021).

30. Edwards, R.B. Export Agriculture and Regional Development: Evidence from Indonesia. In Proceedings of the North East Universities Development Conference, Cornell University, Ithaca, NY, USA, 26 October 2018.

31. Hitchner, S.L. Heart of Borneo as a 'Jalan Tikus': Exploring the Links Between Indigenous Rights, Extractive and Exploitative Industries, and Conservation at the World Conservation Congress 2008. Conserv. Soc. 2010, 8, 320-330. [CrossRef]

32. Leonald, L.; Rowland, D. Drivers and Effects of Agrarian Change in Kapuas Hulu Regency, West Kalimantan, Indonesia. In Agrarian Change in Tropical Landscapes; Deakin, E.L., Kshatriya, M., Sunderland, T.C.H., Eds.; Center for International Forestry Research (CIFOR): Bogor, Indonesia, 2016; pp. 91-138.

33. Roslinda, E. Economic Valuation of the Danau Sentarum National Park, West Kalimantan, Indonesia. Biodiversitas J. Biol. Divers. 2019, 20, 1983-1989. [CrossRef]

34. Giesen, W.; Aglionby, J. Introduction to Danau Sentarum National Park, West Kalimantan, Indonesia. Borneo Res. Bull. 2000, 31, $5-28$.

35. Jeanes, K.; Meijaard, E. Danau Sentarum's Wildlife. Part 1: Biodiversity Value and Global Importance. Borneo Res. Bull. 2000, 31, 150-229.

36. Van Balen, S.; Dennis, R.H. Birds of Danau Sentarum. Borneo Res. Bull. 2000, 31, 336-358.

37. Kottelat, M.; Widjanarti, E. The Fishes of Danau Sentarum National Park and the Kapuas Lakes Area, Kalimantan Barat, Indonesia. Raffles Bull. Zool. 2005, 13, 139-173.

38. Jong, N.H. Palm Oil Plantations, Coal Mines Linked to Deadly Indonesia Flood. Mongabay. 2012. Available online: https: // news.mongabay.com/2021/01/palm-oil-plantations-coal-mines-deforestation-indonesia-south-kalimantan-flood/ (accessed on 7 April 2021).

39. Greenpeace. Down to Zero. How Greenpeace is Ending Deforestation in Indonesia. 2003-2013 and Beyond; Greenpeace South East Asia-Indonesia: Bangkok, Thailand, 2013.

40. Jonas, H.; Abram, N.K.; Ancrenaz, M. Addressing the Impact of Large-Scale Oil Palm Plantations on Orangutan Conservation in Borneo: A Spatial, Legal and Political Economy Analysis; International Institute for Environment and Development (UK): London, UK, 2017. Available online: https:/ / pubs.iied.org/sites/default/files/pdfs/migrate/12605IIED.pdf (accessed on 8 April 2021).

41. Bruno Manser Fonds. The Mulu Land Grab. Report by the Bruno Manser Fonds; Manser Fonds: Basel, Switzerland, 2019.

42. Butler, R.A. Tradeoff: Sabah Banks on Palm Oil to Boost Forest Protection. Mongabay. 2014. Available online: https://news, mongabay.com/2014/12/tradeoff-sabah-banks-on-palm-oil-to-boost-forest-protection/ (accessed on 8 April 2021). 
43. Rakyat Post. DAP: Why Was Oil Palm Project Approved in Forest Reserve in Sabah? Rakyat Post, Malaysia. 2014. Available online: http:/ / www.therakyatpost.com/news /2014/11/27/dap-oil-palm-project-approved-forest-reserve-sabah/ (accessed on 8 April 2021).

44. Horton, A.J.; Constantine, J.A.; Hales, T.C.; Goossens, B.; Bruford, M.W.; Lazarus, E.D. Modification of river meandering by tropical deforestation. Geology 2017, 45, 511-514. [CrossRef]

45. Hearn, A.J.; Joanna Ross, J.; Bernard, H.; Bakar, S.A.; Goossens, B.; Hunter, L.T.B.; Macdonald, D.W. Responses of Sunda Clouded Leopard Neofelis Diardi Population Density to Anthropogenic Disturbance: Refining Estimates of its Conserva-tion Status in Sabah. Oryx 2019, 53, 643-653. [CrossRef]

46. ADP. Heart of Borneo: Saving Forests in Southeast Asia; Asian Development Bank (ADP): Manila, The Philippines, 2013. Available online: https:/ / www.adb.org/news/features/heart-borneo-saving-forests-southeast-asia (accessed on 8 April 2021).

47. WWF. Business Solutions: Delivering the Heart of Borneo. Focus on Forestry, Palm Oil and Mining; WWF-Indonesia: Jakarta, Indonesia, 2011. Available online: https:/ / wwfint.awsassets.panda.org/downloads/wwf_heartofborneo_greenbusinessnetwork. pdf (accessed on 9 April 2021).

48. Kapoor, M.; Menon, M.; Viswanathan, V. Midcourse Manoeuvres: Community Strategies and Remedies for Natural Resource Conflicts in Indonesia; Centre for Policy Research-Namati Environmental Justice Program: New Delhi, India, 2018.

49. Schücking, H. Banking on Coal. Bank Track. CEE Bankwatch Network: Prague, Czechia; Polska Zielona Sieć: Poland (in Cooperation with: Rainforest Action Network: California, United States; World Development Movement: London, UK; Power Shift: Washington, DC, USA) 2013. Available online: https:/ /www.banktrack.org/download/banking_on_coal/banking_on_ coal_updated.pdf (accessed on 9 April 2021).

50. Ministry of National Development Planning. Central Kalimantan: Moving Towards Green Growth; Ministry of National Development Planning: Jakarta, Indonesia, 2015.

51. WALHI; WDM; LMN; DTE; FOE. BHP Billiton's IndoMet Project: Digging Deep into the Heart of Borneo. Indonesia: WALHI (Indonesian Forum for the Environment/Friends of the Earth In-donesia); London: World Development Movement; London: London Mining Network (LMN); Indonesia: Down to Earth (DTE; Australia: Friends of the Earth Australia (FOE Australia), 2014. Available online: https://www.globaljustice.org.uk/sites/default/files/files/resources/indo-met_project_factsheet_lowrez.pdf (accessed on 9 April 2021).

52. Global Energy Monitor. IndoMet Coal Project; Global Energy Monitor: San Francisco, CA, USA, 2020.

53. Alamgir, M.; Campbell, M.J.; Sloan, S.; Suhardiman, A.; Supriatna, J.; Laurance, W.F. High-risk Infrastructure Projects Pose Imminent Threats to Forests in Indonesian Borneo. Sci. Rep. 2019, 9, 140. [CrossRef] [PubMed]

54. Choy, Y.K. Dam-induced Development, Environmental and Social Sustainability-The Bakun Industrialization Strategy Revisited. J. Econ. Issues 2005, 39, 123-150. [CrossRef]

55. Heng, E.S. Trusan Dam Project to Proceed as Planned; Borneo Post: Sarawak, Malaysia, 2017. Available online: https://www. theborneopost.com/2017/07/22/trusan-dam-project-to-proceed-as-planned/ (accessed on 10 April 2021).

56. Choy, Y.K. Land Ethics from the Borneo Tropical Rain Forests in Sarawak, Malaysia: An Empirical and Conceptual Analysis. Environ. Ethics 2014, 36, 421-441. [CrossRef]

57. Choy, Y.K. Ecosystem Health, Human Existence and Bio-capacity Deficit: The Ethical Relationship. Int. J. Sustain. Dev.Plan. 2016, 11, 1004-1016. [CrossRef]

58. WWF. Forests of Borneo; WWF Indonesia: Jakarta, India, 2007. Available online: https://wwfeu.awsassets.panda.org/downloads/ borneo_forest_cc_final_12nov07_lr.pdf (accessed on 3 April 2021).

59. Verwer, C.; van der Meer, P. Carbon Pools in Tropical Peat Forest. Towards a Reference Value for Forest Biomass Carbon in Relatively Undisturbed Peat Swamp Forests in Southeast Asia; Alterra-Report 2018; Alterra: Wageningen, The Netherlands, 2010.

60. Asner, G.P.; Brodrick, P.G.; Philipson, C.; Vaughn, N.R.; Martin, R.E.; Knapp, D.E.; Heckler, J.; Evans, L.J.; Jucker, T.; Goossens, B.; et al. Mapped Aboveground Carbon Stocks to Advance Forest Conservation and Recovery in Malaysian Borneo. Biol. Conserv. 2018, 217, 289-310. [CrossRef]

61. Leung, H. 66 People Have Died in Indonesia's Devastating Floods. Here's What to Know. Time. 2020. Available online: https: / / time.com/5761097/jakarta-indonesia-floods/ (accessed on 10 April 2021).

62. United Nations. Rio Declaration on Environment and Development; UN.Doc. A/CONF.151/26 (Volume I); United Nations: Washington, DC, USA, 1992. 